\title{
Considerations on the Use of Instagram as a Pedagogical Tool under the View of Contextualized Education
}

\author{
Vitor Hugo Rodrigues Carvalho, Dinani Gomes Amorim, \\ Ricardo José Rocha Amorim, Ricardo Barbosa Bitencourt \\ Bahia State University, Juazeiro, Bahia, Brazil \\ Email: vhr.carvalho@hotmail.com, dinaniamorim@gmail.com, \\ amorim.ricardo@gmail.com ricardo.bitencourt@ifsertao-pe.edu.br
}

How to cite this paper: Carvalho, V. H. R., Amorim, D. G., Amorim, R. J. R., \& Bitencourt, R. B. (2021). Considerations on the Use of Instagram as a Pedagogical Tool under the View of Contextualized Education. Creative Education, 12, 1679-1691. https://doi.org/10.4236/ce.2021.127128

Received: May 4, 2021

Accepted: July 24, 2021

Published: July 27, 2021

Copyright $\odot 2021$ by author(s) and Scientific Research Publishing Inc. This work is licensed under the Creative Commons Attribution-NonCommercial International License (CC BY-NC 4.0). http://creativecommons.org/licenses/by-nc/4.0/

\begin{abstract}
The present work is part of a larger research that is being developed and that aims to develop a strategy for using the Instagram social network as a pedagogical tool that enables active and contextualized learning. The origin of this research is based on the researcher's empirical experiences, in which some difficulties that exist for the insertion of technologies in teaching practices were perceived. However, this research aims to go beyond the relationship between technologies and educational practices, as the work is based more specifically on the fundamentals of the Contextualized Education perspective. In this way, this article aims to reflect on the possibilities of articulation between the social network Instagram with the proposal of Contextualized Education. For this, a literature review was carried out and it was possible to consider that the potential of the use of technologies in education converges with what the contextualized education proposal aims at and that Instagram resources have the potential to enhance the contextualization proposal provided that they are used as instruments for critical and reflective learning. However, there are still obstacles to achieving this articulation in teaching.
\end{abstract}

\section{Keywords}

Digital Media, Contextualized Education, Technologies in Education

\section{Introduction}

This work had as a starting point the research that is being developed in the Master's program in Education, Culture and Semiarid Territories, at the State 
University of Bahia (UNEB), Juazeiro Campus, in the State of Bahia, in Brasil, on the use of the social network Instagram as a pedagogical tool for active and contextualized learning.

The author's motivation for the conception of this investigation originated from his experiences. During his studies, the author participated in some disciplines that used social networks as a pedagogical tool and observed positive results regarding the knowledge acquired by himself and the class. These experiences as a subject of practice made him realize the potential of social networks as a pedagogical tool, provided they are applied effectively. In addition, these events in which he participated made him reflect on the gaps, errors and possibilities of further exploring the resources of social networks on the internet.

In addition, the author took into account the report of colleagues who are teachers about the difficulty in creating pedagogical strategies with the use of Information and Communication Technologies (ICTs) because of the resistance or the difficulty of teachers regarding the use of ICTs for the educational purpose. Furthermore, there are obstacles such as low connection ranges in schools, restricted use of the network for administration and school institutions that prohibit the use of cell phones during classes. In view of this, the willingness to contribute to studies on the use of ICTs as a pedagogical tool was manifested; however, the research goes beyond this, as it is based on the perspective of Contextualized Education (CE).

$\mathrm{CE}$ is a reflective paradigm in the perspective of curriculum that strives for an education that dialogues with the local knowledge of the subjects' reality. The theoretical-methodological path of $\mathrm{CE}$ is the pedagogy of projects, a pedagogy that requires research, reflection, creativity, interaction with people's reality (Teles, Bento, \& Santos, 2017).

In order to understand the CE proposal first, it is necessary to understand what contextualization is. Contextualization occurs when you align something according to time and the world. Contextualizing teaching and learning is a challenge for teachers (Tufano, 2002), especially in the face of an informational and dynamic society. When thinking about contextualization in education, it is necessary to understand that the changes in society resulting from the use of ICTs have impacted the profile of today's students.

Globalization has brought challenges to education that also affect the proposal of Contextualized Education. Today people have the possibility to be authors and propagators of information and not just recipients. The resources of the digital space form a wide network of shared data, in the so-called cyberspace, which brought a new cultural configuration to the beginning of the 21 st century (Lemos, 2005).

These cultural transformations caused changes in the student's profile. Prensky (2001) discusses about the contrast between students and teachers in the classroom and explains that students are considered digital natives in view of the innate expertise of their generation in terms of handling ICTs and how to learn 
multiple things at the same time. The student's profile is opposed to that of the teacher, considered a digital immigrant, due to not having grown up using technology and still try to adapt to the speed of changes provided by the media (Prensky, 2001; Mattar, 2010).

In such a way, considering the cultural transformations brought about in society, to contextualize teaching and learning with time and with the world, it is necessary to understand the changes in the profile of contemporary students, their relationship with the use of ICTs, what it implies in the teaching practices and how ICTs can be allied for the perception of students' contexts.

Given the above, it is proposed to reflect on the relationship between Contextualized Education and the use of ICTs in educational practices through a review of the literature on the respective themes. First, it was decided to explain what the Contextualized Education paradigm is, and then reflect on how digital technologies can be associated with this proposal. Finally, some considerations were made about the study highlighting the positive potential and the challenge that this association is.

\section{The Contextualized Education Proposal}

The Contextualized Education is an interdisciplinary process in addition to raising the awareness of the subjects, aspire it involves them with the issues of their own reality. In the $\mathrm{CE}$, the subjects are central participants in the process of construction of the pedagogical practice, so that it dialogues with their life stories and their knowledge and tries to make them reflect on their own experiences to awaken a new, more critical look, of the world (Teles, Bento, \& Santos, 2017).

There is permanent flexibility in the CE proposal since it is a construction related to the context. This characteristic requires interactivity and creativity for your practice, and it is not possible to restrict yourself to a script with precise rules. Therefore, the path of $\mathrm{CE}$ is not defined and it is necessary to understand the propositions of each situation (Teles, Bento, \& Santos, 2017).

That said, in order to carry out contextualized practices, it is necessary to first understand what context and contextualization are and the relevance of contextualized teaching and learning for the formation of the subject. Contextualization is a process of systematization and continuous recreation. Even in places that already work in this perspective of Contextualized Education, it does not lose its dynamic character since its application in practice is done together with the participation of subjects taking into account their contexts (Teles, Bento, \& Santos, 2017).

The collaborative and democratic methodological perspective of CE meets banking education and shares the liberating pedagogy proposed by Freire (1987), who says that an education that does not allow an approximation with the political, social and cultural context of the subjects corroborates with relations of domination and oppression. CE is also related to the vision of Marx and Engels, in which only education, science and the extension of knowledge could 
be an instrument of transformation of the individual capable of making him aware of the relations of domination and oppression that he is inserted in and thereby achieving his liberation (Lombardi, 2011).

Marx and Engels criticize the perspective that considers the School as a strictl school fact, that is, a self-sufficient phenomenon independent of the social and political issues that permeate the school context (Lombardi, 2011). The CE proposal meets Marx's ideas, in the sense of because in it the school curriculum must be integrated into the reality of the subjects.

The Contextualized Education approximates saying to do, the discourse of practice, as it is based on the study of reality to transform it (Teles, Bento, \& Santos, 2017). This perspective proposes a curriculum project with other references, so as not to ignore cultural, gender, race, color and sexual orientation differences. CE aims to rethink the place of the subjects and break with the present colonizing discourses in the approaches of the disciplines. Plurality and multi-referentiality are the main characteristics of a contextualized curriculum (MenezeS \& Araujo, 2007).

Given the above, it is clear that discussions about contextualization cannot be restricted to university classrooms or to the actions of NGOs and Social Movements. This proposal aims to reach the classrooms; however, breaking with a de-contextualized and colonizing curriculum is a challenge for Brazilian teachers, given that the curriculum content in Brazil is already defined by the Department of Education. The official curriculum project does not propose to think about the complexity of the multiple realities of the subjects (Lopes, 2014). To understand this issue of making the curriculum official, it is necessary to reflect on its conception. In reality, the school curriculum is not a ready and neutral product. The idea of a curriculum always has a definite educational intention, has an ideology and is related to some kind of power. It is in its elaboration that it defines what type of citizen it aims to form aiming to attend the interests of hegemonic groups. It is the curriculum that guides the knowledge that will be taught, learned or reworked. Therefore, the curriculum is a space for inclusions or exclusions (Menezes \& Araujo, 2007).

For this reason, in a decontextualized curriculum, cultural diversity appears disconnected and stereotyped in teaching practices and multiculturalism is treated marginally through transversal themes. Cultural diversity is inserted in the school as an exotic element, a tourist element in the school curriculum and not as an integral part of the culture and training of the Brazilian people, their native people. Discussions such as the day of black conscience or the day of the Indian appear in the school calendar in the form of a commemorative date, with a superficial and colonizing discourse, as occurs in schools that dress students as Indians instead of discussing the social problems that the indigenous people currently suffer or value their historical relevance to national culture (Lins, 2013).

The curriculum conception adopted by the CE believes that the teacher must 
be the interdisciplinary bridge that links content and subjects and is an agent of changes in the lives of their students, who, in turn, also transform them (Arnt, 2002; Kachar, 2002; Ramos, 2002). To CE, the curriculum is a political and pedagogical field in which the subjects relate, producing and sharing their knowledge, transforming themselves and society (Menezes \& Araujo, 2007).

It is noticed that the discussion of contextualization in the curricular field considers the different experiences and stories of the subjects as an integral part of the educational processes and aims to bring these different contexts closer to the educational practices (Menezes \& Araujo, 2007). Therefore, the formative stages proposed by the $\mathrm{CE}$ are based on the following pedagogical itinerary: the understanding of reality (political, social or cultural aspects of a context), the scientific treatment of the issues observed and the transformation of reality (Teles, Bento, \& Santos, 2017).

$\mathrm{CE}$ believes that the inequalities present in the school curriculum need to be overcome so that the school does not collaborate with relations of dominance between different cultures, genders and races. For this, issues related to cultural diversity must be addressed at school in addition to the transversal form or the celebration of commemorative dates (Lins, 2013; Barros \& Paiva, 2017). In addition, it is also necessary to reflect on the images that have been reproduced in Brazil about the Brazilian northeast that represent your people through ideas related to poverty, to a difficult life, the dry nature, lack of intelligence and brutality (Barros \& Paiva, 2017).

The Contextualized Education is opposed to stereotyped ideas of the Brazilian Semiarid and is based on respect and valuing of interculturality. The foundation of intercultural understanding is the exercise of allowing oneself to acquire an outward look at their own beliefs in order to perceive a more critical and newer outlook on themselves. It is from this perspective that it is possible to understand another culture, with its own origin, its own imagination and traditions. This exercise is an arduous task and it is not a question of being mystified by the way of life of others, but of knowing that there is something to learn with them (Perrot, 1994). This fundament is called the "boomerang effect" and can be used as a pedagogy of identity and difference. An identity can be enriched by contact with others, however, access to the other will always be relative or limited, so that a subject will not begin to see the world as someone from another culture, or understand everything about it (Perrot, 1994).

The CE has as principles the research, reflection, creativity, interaction with the reality of the subjects. It requires theory and action, to later propose interventions that will contribute to the improvement of the situations encountered (Teles, Bento, \& Santos, 2017). However, in order to take this teaching proposal to the students, there is another obstacle: teacher training on the Brazilian Semiarid. Teachers still find it difficult to find ways to bring their teaching practice closer to the subjects' context and stories, also, often their own understanding of the Semiarid is limited (Lopes, 2014). 
The Brazilian semiarid region covers a large part of the states in the Northeast, and is defined by irregular rainfall in its territory. The media generally portrays the Brazilian Semiarid through many stereotypes of poverty, precariousness, which has people "without intelligence", tainted by hostile nature (Barros \& Paiva, 2017).

This contempt for the Brazilian Semiarid present in the media disguises its potentials and reinforces ideas so distorted that the subjects belonging to these regions themselves do not see themselves in this reality. In this way, the inhabitants of the Brazilian Semiarid undergo a process of non-identification as members of their own region, or, in many cases, because they were so colonized by external ideas, they start to assume the caricatures painted on them as true. The Brazilian Semiarid region is little known, it is reduced to the idea that it is a dry, hot place, surrounded by cacti and suffering from a lack of water. This limitation of the Brazilian Semiarid concept renounces its meaning as the territory of a people that has a unique, rich and diverse identity and culture (Lopes, 2014).

\section{The Articulation between Contextualized Education and the Use of Digital Technologies as a Pedagogical Tool}

At first, it is necessary to understand what results the use of ICTs has been providing when used in teaching processes. And based on that, understand how they can be related to the proposal of Contextualized Education. In this sense, in order to better understand the materials that have been published on the use of technologies aimed at learning, a consultation was carried out in some databases and scientific journals in order to understand the social and academic relevance of this topic.

Among the total scientific papers found, a sample was selected based on some inclusion criteria:

- Articles published in the period between 2015 to 2019;

- Articles available in the SciELO database;

- Articles found in the scientific journal Renote (New Technologies in Education Magazine);

- Articles available on Google Scholar;

- Empirical or theoretical articles;

- Articles that address the use of mobile technologies in teaching practices, or more specifically, the use of digital media as pedagogical tools.

Following the established criteria, a total of 5 articles were selected:

- New Technologies in Education Magazine (Renote)-3 articles

- SciELO-1 article

- Google Scholar-1 article

In addition to these articles, other works were also analyzed to understand the paradigm of Educommunication and relate the use of ICTs to Contextualized Education.

Among the selected articles, three of them analyzed the educational potential 
of using social media (Facebook, YouTube and Whatsapp) as a pedagogical tool for active and collaborative learning and it was possible to identify positive points in the construction of active and collaborative learning, in which students are more responsible for their own learning. These researches showed that the use of social networks in an educational context contributed to a more critical and reflective formation of knowledge (Souza et al., 2017; Quintanilha, 2017; Kaieski, Grings, \& Fetter, 2015).

The research by Martins et al. (2018) presented a systematic review of the literature that made it possible to point out some benefits of using technologies for learning. This study pointed out that learning with the use of technologies can motivate and engage students with educational activities and insert them in a research process stimulating cooperation between colleagues, reflection and critical thinking by students.

In addition, combining the new media in the educational processes allowed the students to learn more inside and outside the classroom and made the students' study more flexible. These results show a more active, critical and reflective teaching provided by the use of ICTs commune with the perspective of Contextualized Education CE and dialogue with the view of Paulo Freire (1987) on education.

Therefore, strategies for appropriating ICTs can be created to enhance the discourses associated with the context in which the subject is interwoven. This role in the use of the media in a critical-reflexive way can collaborate with the breaking of stereotypes present in the mass discourses that represent the Brazilian Semiarid in a stereotyped way, as a place always linked to the idea of miserability and suffering, with a motto of colonizing intent. In this way, the media can be important allies for Contextualized Education, both in the processes of construction and communication of new discourses regarding the Brazilian Semiarid Region and in the dissemination of students' knowledge about their social, political and cultural reality (Teles, Bento, \& Santos, 2017).

However, Purimi and Tizzotii (2019) point out that combining technologies in teaching practices will require training of teachers to use technologies applied to education, therefore requiring financial investments for this purpose. In addition, these authors emphasize that, despite the positive contributions of the use of technologies aimed at students' learning, strategies and rules must be established so that the use of social networks for pedagogical purposes is more responsible and effective.

The research by Martins et al. (2018) brought some gaps that should be better investigated in future academic works such as: new educational practices with the use of technologies and the consequences of using new resources in the teaching and learning process. Martins et al. (2018) also highlight the importance of a deeper understanding of digital literacy by teachers. Soares et al. (2018) point out that the use of social networks in the classroom requires the teacher to adopt a new posture in the classroom, with planning and mediation of 
activities being attributed to him.

Through the analysis of these articles, it is clear that thinking about digital technologies applied to education is a dynamic process that requires teachers, even if they are digital immigrants (Prensky, 2001), to leave their comfort zone in search of promoting a pedagogical strategy that articulates the technologies, but does not neglect the objective of monitoring the students' learning (Martins et al., 2018; Purimi \& Tizzotii, 2019).

Soares (2017), points out that ICTs cannot be the center of processes, leaving them only the role of allies for this purpose. In this line of reasoning, Soares (2017) brings the concept of Educommunication, a proposal that aims to articulate communicative practices in educational contexts. The means of communication, media and ICTs are seen as instruments that enhance the learning and the protagonism of the students in relation to their reality.

Educommunication is a transversal and transdisciplinary discursive paradigm and its fundamental practice is dialogical communication and highlights the management of communication in school spaces that also involve the media and Information and Communication Technologies (ICTs). Educommunication proposes to think and act critically in relation to reality, interact and propose transformations (Soares, 2011). In it the curriculum is thought from the subjects and not in the communication processes. This proposition has as value the collaborative and democratic use of ICTs in order to foster citizenship (Teles, Bento, \& Santos, 2017).

There are convergences between Educommunication and the CE proposal. Both promote the subject's self-knowledge in order to promote a strangeness resulting from a new, more critical look at the world. The concerns caused by both fields are reflected in the formulation of a new way of thinking, acting and, consequently, in the transformation of oneself and society (Teles, Bento, \& Santos, 2017).

Therefore, education can think of technological devices as instruments that enable the construction and communication of a new look at the world. Through digital technologies it is possible to enhance the perception of context, local cultures, different world views, as well as enhance the communication of this knowledge (Teles, Bento, \& Santos, 2017). Therefore, it is clear that digital technologies can be important allies for the proposal of Contextualized Education.

\section{Possibilities of Using Instagram Based on the ECSAB Perspective}

Instagram is currently one of the most popular internet social networks in the world, with an emphasis on the audience of young and adult audiences (Statista, 2020). In June 2018 it registered 1 billion global users (Statista, 2019) and according to the ranking released by Statista (2020), Brazil is the third country with the most users on Instagram, with 77 million users in January 2020, standing behind India and the United States.

This social network has the main function of sharing and editing photos. You 
can take photos through the app or choose an image from the phone's gallery to post to your account. Before sharing an image with other users, you can customize the photo through filters available in the program (Statista, 2019).

Since 2016, Instagram Stories has been added to the network, a function for sharing images or short videos that disappear 24 hours after being published. The Stories proposal initially was that the user could take a photo in real time with the possibility of quick editing and adding text boxes with options for customizing colors and backgrounds, stickers, emojis, gifs, among others (Techtudo, 2018b).

Instagram allows you to capture images and videos and share on social networks with contacts that follow the user's profile. Shared images can be linked to text. It is possible to write up to 2,200 characters in the caption of each image posted on a wall in the account. The interaction with other users can be done by viewing the published content, the "like" button, the option of comments and the function that allows you to share the content you are accessing in your account with other users in your network of followers (Techtudo, 2018b).

Over time more features have been added to Instagram Stories. Today there is the possibility to mention friends' accounts and it is possible to choose images or videos to be kept in prominence on the social network for as long as the user wishes, no longer being restricted to the 24-hour period.

Instagram Stories are currently more interactive. It is possible to elaborate questions and polls for the followers of the account and, in addition, this story sharing function allows to carry out video transmissions in real time (Techtudo, 2018b).

To ask a question the user can write a text in an open field for other users to answer. Comments are grouped together with the list of question views. To answer, the user reposts the question in Stories by adding texts and even visual resources such as emojis and gifs (Techtudo, 2018a).

In the case of the poll, which is also a function linked to Instagram Stories, it is possible to ask a question and create two options as an answer. Account followers will be able to interact with the poll by tapping the option buttons. The result is given in real time and shows the percentage of followers who chose each option (Techtudo, 2017).

In short, on Instagram it is possible to create a network of people who interact with content produced by one or more users and have a range of resources to make that content attractive to their audience. That said, the school can use these possibilities for students to build and dialogue about the knowledge they are learning in an interactive and interconnected way on the internet.

Therefore, it is hypothesized that the use of Instagram can lead to positive results with regard to the proposal of Contextualized Education. Thinking about teaching practice with contextualization as the thematic axis of the curriculum is an interdisciplinary proposal. In the proposed research that is under development, the discipline chosen to test the articulation of Instagram with Contextua- 
lized Education was geography. It is intended to create and to use a pedagogical practice with use of Instagram's multimedia resources.

Instagram is related to this research, because it is a predominantly visual social network in which images and videos are displayed bringing relevant content to the subjects and social relations. This digital media is then thought of as a tool for students to be able to use the potentials relevant to it to build knowledge about geography and added to them their lived knowledge and their understanding of the world.

The choice of the association between Instagram for the teaching of geography is reinforced by the research by Júnior \& Aguiar (2019), which found a great evolution in student learning by integrating Instagram as a pedagogical tool in the teaching of geography, and the use of social network made learning enjoyable for absorbing the content worked on. The research, however, is not based directly on the principles of Contextualized Education. A pertinent challenge to the larger research that is underway, in which this article is part.

In the school routine, it is the responsibility of the teacher to transmit the learning objectives of the content from the perspective of contextualization, clinging to elements that the students know to anchor new meanings aiming at meaningful learning. However, it is necessary to think about the scenario in which the teacher does not know the proposal of Contextualized Education. Therefore, it is necessary to create strategies that facilitate the exercise of thinking about curricular content based on the principles of CE.

Instagram can be a device capable of awakening the students' learning motivation considering the active profile and used to the technologies of digital natives, as it was observed in the researches that have been carried out by Júnior \& Aguiar (2019), Pereira, Júnior and Silva (2019), Alcântara (2019).

In the research by Júnior \& Aguiar (2019), there was a high level of interest and engagement from the students, which reinforces the positive aspect of the student's role in the construction of their learning and through this research, it was noticed the potential of Instagram for the perception of the environment, of different geographical landscapes, with a keen eye for the perception of inequalities.

Pereira, Júnior and Silva (2019), point out gaps in the teaching of chemistry due to the lack of contextualization with the students' daily life and the difficulty of reflections and learning the concepts. The study was successful in articulating the social network Instagram focused on teaching chemistry, and a positive result was found in the methodology used to understand the concepts of chemistry from a less mechanical, more pleasant and collaborative learning methodology.

The results of the research indicated that the use of a social network facilitated teamwork and the autonomy given to students made them share their skills and knowledge with each other in order to resolve the propositions. In addition, the students who participated in the research improved their ability to synthesize information and carrying out the experiment generated the need to use other technological tools such as image, video and text editing applications, which 
contributed to digital inclusion (Pereira, Júnior, \& Silva, 2019).

In the study by Alcântara (2019), the researcher used publications in Instagram's Stories function to verify if this tool could be useful in the dissemination of scientific information. The research concluded that the use of Instagram's Stories mechanism instigated the students' curiosity and provided a fun and learning moment and that this tool is relevant for the dissemination of scientific information. And with regard to satisfaction with the performance of the activity, 99\% of the participants reported that they very much liked the approach through this methodology and that it should be used more often over other concepts.

\section{Conclusion}

In light of the readings on the perspective of Contextualized Education and the literature review on the use of ICTs applied in educational processes, it is clear that the use of technologies as a pedagogical tool obtained results that converge with the principles of CE and that Instagram shows positive potentials for its articulation with the contextualization point of view. It can be said, therefore, that Instagram has potential as a tool for promoting $\mathrm{CE}$ and for a more active and enjoyable learning for students.

Given this, the appropriation of multimedia resources pertinent to Instagram by subjects from different contexts has the potential to contribute to the production and dissemination of knowledge about their reality as a way of empowerment and fostering citizenship. However, currently there are difficulties both in promoting contextualized educational practices and in the articulation of ICTs for learning, which makes the correlation of both an even greater challenge. Therefore, it is relevant to think about useful strategies for this purpose to assist in teaching practices that aim to use contextualization in teaching using digital media.

\section{Acknowledgements}

Thanks are due to the Foundation for Research Support of the State of Bahia (FAPESB) for the resources that contributed to the development of this research.

\section{Conflicts of Interest}

The authors declare no conflicts of interest regarding the publication of this paper.

\section{References}

Alcântara, L. F. M. (2019). Storie do Instagram: Um ambiente de discussão sobre inflamação. Anais do $4^{\circ}$ Congresso Nacional de Pesquisa e Ensino em Ciência CONAPESC, Campina Grande, September 2019, 2525-6696.

Arnt, R. M. (2002). Mudança. In I. C. A. Fazenda (Ed.), Dicionário em construção: Interdisciplinaridade (2nd ed., pp. 73-74). Cortez.

Barros, E. R., \& Paiva, C. C. S. (2017). Paradigma Cultural II: Gênero, educação, trabalho e etnias. PR: CRV, Curitiba. 
Freire, P. (1987). Pedagogia do oprimido (17th ed.). Paz e Terra. http://www.editorarealize.com.br/artigo/visualizar/57243

Júnior, A. F. G., \& Aguiar, B. R. (2019). A cidadania, o cyber-espaço e o ensino de Geografia: A rede social Instagram como possibilidade na prática pedagógica. Anais do $14^{\circ}$ Encontro Nacional de Prática de Ensino de Geografia Políticas, Linguagens eTrajetórias ENPEG, Campinas, July 2019, 2639-2649. https://ocs.ige.unicamp.br/ojs/anais14enpeg/article/view/3101/2964

Kachar, V. (2002). Ponte. In I. C. A. Fazenda (Ed.), Dicionário em construção: Interdisciplinaridade (2nd ed., pp. 75-78). Cortez.

Kaieski, N., Grings, J. A., \& Fetter, S. A. (2015). Um estudo sobre as possibilidades pedagógicas de utilização do Whatsapp. Renote, 13, 2-10.

https://doi.org/10.22456/1679-1916.61411

Lemos, A. (2005). Ciber-cultura-remix. http://www.facom.ufba.br/ciberpesquisa/andrelemos/remix.pdf

Lins, C. M. A. (2013). Livros didáticos contextualizados conhecendo o Semiárido volumes 1 e 2: Aspectos políticos/pedagógicos no percurso de elaboração. In E. S. R. Reis, M. L. S. Nobrega, \& L. D. Carvalho (Eds.), Educação e Convivência com o Semiárido. Reflexões por dentro da UNEB (2nd ed., pp. 86-103). UNEB.

Lombardi, J. C. (2011). Textos sobre Educação e Ensino: Karl Marx e Friedrich Engels, Navegando, Campinas.

Lopes, M. C. (2014). Educação contextualizada voltada para a realidade dos sujeitos que vivem no semiárido. In J. Marques, L. Dourado, \& R. Sena (Eds.), Itinerários e Contextos: Reflexões em educação e convivência com o semiárido brasileiro (pp. 97-105). Printpex.

Martins, E. R., Geraldes, W. B., Afonseca, U. R., \& Gouveia, L. M. B. (2018). Tecnologias Móveis em Contexto Educativo: Uma Revisão Sistemática da Literatura. Renote, 16, 2-10. https://doi.org/10.22456/1679-1916.85926

Menezes, A. C. S., \& Araujo, L. M. (2007). Currículo, Contextualização e Complexidade: Espaço de interlocução de diferentes saberes. In E. S. Reis (Ed.), Currículo, Contextualização e Complexidade (pp. 33-47). Resab.

Pereira, J. A., Júnior, J. F. S., \& Silva, E.V. (2019). Instagram como ferramenta de aprendizagem no ensino de Química. Redequim, 5, 119-131. http://www.journals.ufrpe.br/index.php/REDEQUIM/article/view/2099

Perrot, M. D. (1994). Educar para o desenvolvimento e a perspectiva intercultural. In A. Faundez (Ed.), Educação, desenvolvimento e cultura: Contradições teóricas e práticas (pp. 191-212.). Cortez.

Prensky, M. (2001). Digital Natives, Digital Immigrants. On the Orizon, 9, 1-6. https://www.deepdyve.com/lp/emerald-publishing/digital-natives-digital-immigrants-p art-1-ZKtTij0fQT https://doi.org/10.1108/10748120110424843

Purimi, K. S. M., \& Tizzotii, E. L. A. (2019). Protagonismo dos Estudantes de Medicina no Uso do Facebook na Graduação. Revista Brasileira de Educação Médica, 43, 187-196. https://doi.org/10.1590/1981-52712015v43n1rb20180139

Quintanilha, L. F. (2017). Inovação pedagógica universitária mediada pelo Facebook e YouTube: Uma experiência de ensino-aprendizagem direcionado à geração-Z. Educar em Revista, 33, 249-263. https://doi.org/10.1590/0104-4060.50027

Ramos, G. T. (2002). Mudança. In I. C. A. Fazenda (Ed.), Dicionário em construção: Interdisciplinaridade (2nd ed., pp. 68-72). Cortez. 
Soares, A. B., Botega, S. P., Santos, L. M. A., Ellensohn, R. M., \& Barin, C. S. (2018). Construindo saberes nas redes sociais. Renote, 16, 2-10. https://doi.org/10.22456/1679-1916.85991

Soares, I. O. (2011). Educomunicação: Um campo de mediações. In A. O. Citelli, \& M. C. C. Costa (Eds.), Educomunicação: Construindo uma nova área de conhecimento (pp. 13-30). Paulinas.

Soares, I. O. (2017). Mas afinal, o que é educomunicação? Núcleo de Comunicação e Educação da Universidade de São Paulo NCEUSP. http://www.usp.br/nce/wcp/arq/textos/27.pdf

Souza, P. I. C., Souza, C. C., Souza, R. P., \& Melo, R. F. (2017). Facebook como Ambiente de Aprendizagem Colaborativa na Disciplina de Banco de Dados. Renote, 15, 2-10. https://doi.org/10.22456/1679-1916.79279

Statista (2019). Instagram-Statistics \& Facts. https://www.statista.com/topics/1882/instagram

Statista (2020). Leading Countries Based on Instagram Audience Size as of April 2020. https://www.statista.com/statistics/578364/countries-with-most-instagram-users

Techtudo (2017). Como fazer uma enquete no Instagram Stories. https://www.techtudo.com.br/dicas-e-tutoriais/2017/10/como-fazer-uma-enquete-no-i nstagram-stories.ghtml

Techtudo (2018a). "Faça uma pergunta": Instagram Stories ganha novo adesivo; veja como usar. https://www.techtudo.com.br/dicas-e-tutoriais/2018/07/instagram-stories-ganha-sticke r-de-perguntas-saiba-usar-o-novo-adesivo.ghtml

Techtudo (2018b). Instagram Stories faz 2 anos; veja a evolução da ferramenta. https://www.techtudo.com.br/noticias/2018/08/instagram-stories-faz-2-anos-veja-a-ev olucao-da-ferramenta.ghtml

Teles, E. C., Bento, A. M. R., \& Santos, E. S. A. (2017). Convergências formativas no contexto da Educação Contextualizada e Educomunicação. In A. H. Roch, E. C. Teles, E. S. Reis, \& F. A. Sá (Eds.), Educação e Reflexão: Reflexões de um Saber-Fazer Coletivo (pp. 387-395). Editora CRV.

Tufano, W. (2002). Contextualização. In I. C. A. Fazenda (Ed.), Dicionário em construção: Interdisciplinaridade (2nd ed., pp. 40-41). Cortez. 